https://idp.uoc.edu

Dossier "Europe facing the digital challenge: obstacles and solutions"

\title{
The European approach to building Al policy and governance: a haven for bureaucrats or innovators?
}

\author{
Olga Shumilo \\ Tallinn University of Technology (TalTech) \\ Tanel Kerikmäe \\ Tallinn University of Technology (TalTech)
}

Date of submission: May 2021

Accepted in: November 2021

Published in: December 2021

\begin{abstract}
Disruptive technologies and the domination of digital platforms have challenged the global economy players twice - first, to get a hand on them, then to mitigate the possible risks. It is beyond doubt that reliable artificial intelligence (AI) can bring many benefits at the European level, such as better health care, safer and cleaner transport, more efficient manufacturing, and sustainable energy. But regulating the unknown requires considerable effort on how to attract investors using clear rules while keeping human control over the algorithms as a priority. In April 2021, the EU Commission published a holistic proposal to regulate the use of $\mathrm{Al}$, which promises to put trust first and ensure that facial recognition and big data operators will never abuse fundamental human rights. Although the proposal is likely to be amended during EU-wide discussions, the new approach to Al will clearly give citizens the reassurance to adopt these technologies while encouraging companies to develop them. Hence, this article aims to map the core challenges for the EU policy on the use of $\mathrm{Al}_{\mathrm{l}}$ as well as the milestones of developing the holistic legislative proposal, and clarify if the afore-mentioned proposal indeed solves all the Al-related risks for future generations.
\end{abstract}

\section{Keywords}

$\mathrm{Al}$; artificial intelligence; EU law; fundamental rights 


\title{
El enfoque europeo para construir la política y la gobernanza de la IA: ¿un refugio para burócratas o innovadores?
}

\section{Resumen}

Las tecnologías disruptivas y el dominio de las plataformas digitales han desafiado a los actores de la economía global dos veces: primero, para echarles una mano, luego para mitigar los posibles riesgos. Está fuera de toda duda que la inteligencia artificial (IA) fiable puede aportar muchos beneficios a nivel europeo, como una mejor atención sanitaria, un transporte más seguro y limpio, una fabricación más eficiente y una energía sostenible. Pero regular lo desconocido requiere esfuerzos considerables sobre cómo atraer inversores con reglas claras y al mismo tiempo mantener el control humano como una prioridad sobre los algoritmos. En abril de 2021, la Comisión de la UE publicó una propuesta holística para regular el uso de la IA, que promete poner la confianza en primer lugar y garantizar que los operadores de reconocimiento facial y big data nunca incumplan los derechos humanos fundamentales. Aunque es probable que la propuesta se modifique durante los debates a escala de la UE, el nuevo enfoque de la IA dará claramente a los ciudadanos la confianza para adoptar estas tecnologías, al tiempo que animará a las empresas a desarrollarlas. Por lo tanto, este artículo tiene como objetivo trazar los principales desafíos para la política de la UE sobre el uso de la IA, así como los hitos del desarrollo de la propuesta holística legislativa, y aclarar si dicha propuesta resuelve realmente todos los riesgos relacionados con la IA para las generaciones futuras.
\end{abstract}

\section{Palabras clave}

IA; inteligencia artificial; derecho de la UE; derechos fundamentales 


\section{Introduction}

Since their emergence, artificial intelligence (hereinafter Al) systems have become a topic of hot debate, fuelled by a lack of understanding of algorithms and their potential to change the world for the better. In 1973, the so-called Lighthill report buried the boom of Al research in Great Britain for a decade, based on the rapporteur's observation that building able robots has so far failed to deliver any practical value and thus had to be discontinued for the sake of funding more relevant research (Agar, 2020). The 21 st century has brought great success to the developers of automated solutions, and digital platforms are more than eager to employ disruptive technologies to skyrocket operational efficiency (Arrieta et al., 2020). The Al has also challenged us to redefine the phenomena of non-discrimination and fairness (BBC, 2021) since the proverbial errare humanum est formula reminds us of the eternal prejudice behind public administrations. The rapid adoption of the technology in the public sector has led to inevitable mistakes that proved that the risks of predictions provided a black box fed by human input. Apart from the notoriously dystopian results of the Al-backed COMPAS system (Black \& Murray, 2019), we have to acknowledge the fact that algorithms are powerful enough to transform any sphere of human activity into a race for higher efficiency, be it anti-plagiarism plugins (Büttner et al., 2015) or weaponry (Cabral, 2020). These and other risks have triggered the discussion on how to elaborate a human-centred approach to developing these technologies, which coined terms like XAI (eXplainable Al) (Arrieta et al., 2020) and responsible Al (CEN-CENELEC, 2020). Naturally, lawmakers across the globe were eager to pioneer a solution that would please all the stakeholders. Still, it was of particular significance for the EU, given the high priority of human rights protection enshrined in the Charter (Charter of the Fundamental Rights of the Union, 2012) and the worldwide recognition of the mechanisms established by the General Data Protection Regulation (2018).

Considering the above, the current article aims to portray the institutional approach for defining $\mathrm{Al}$, as well as the driving forces and barriers behind the EU Al policy in chapter 1 , in order to offer a critical perspective on the Al policy steps taken by the main EU stakeholders so far, with a specific focus on the recent horizontal legislative proposal for regulating $\mathrm{Al}$, in chapters 2 and 3. Consequently, we raise the research question on whether the new European regulatory framework is answering the technology challenges and able to foster international cooperation in the field. Methodologically, we rely on desktop-based literature analysis and assessments by innovation experts to substantiate our evaluation of the EU AI policy concerning the mentioned aims. The authors strive to bridge the existing gap in the literature on the forthcoming Al regulation proposed by the European Commission and scrutinize any possible drawbacks that the draft may have.

\section{Defining the drivers and barriers of EU-wide Al systems regulation policy}

Modern literature offers a plethora of definitions for $\mathrm{Al}_{\text {, }}$ or 'thinking machines', since back in Alan Turing's era it was hard to come up with a unanimous understanding for words such as machin' and to think. ${ }^{1}$ For example, the modern computer science doctrine offers a working definition for Al as a 'similarity between a typical human mind $H_{\text {... }}$ and a typical intelligent computer $C_{\text {...., in which }}$ the two are described with a certain level of abstraction' (De Hert et al., 2016). But legal interpretations ought to be inclusive, precise, comprehensive, and practical (Delponte, 2018), i.e., to unequivocally delineate the threshold degree of a particular agent's autonomous ability to mimic human behaviour. This is also why policymakers focus mainly on so-called 'weak' Al - the development of a fully autonomous $\mathrm{Al}$ or artificial general intelligence (AGI) is theoretically challenged by many, ${ }^{2}$ or at least not foreseen to arrive anytime soon. However, such a creature would definitely require a new layer of legislation covering its function in human society.

The definition of $\mathrm{Al}$ in EU strategic documents also varies, from "a collection of technologies that combine data, algo-

1. EUR-Lex-12012P/TXT. Charter of Fundamental Rights of the European Union. Official Journal C326, 26 October, pp. $391-407$.

2. EUR-Lex-32001L0095. Directive 2001/95/EC of the European Parliament and of the Council of 3 December 2001 on General Product Safety, Official Journal L 11, 15 January 2002, pp. 4-17. 
rithms and computing power" to "software that is developed with one or more of the approaches and techniques listed in Annex I and that, for a given set of human-defined objectives, can generate outputs such as content, predictions, recommendations, or decisions affecting the environments they interact in" (Al Regulation Proposal, 2021). The latter is complemented with the following Annexes that help to define the taxonomy of Al technologies:

- Machine learning (including supervised, unsupervised, and reinforcement learning, using a wide variety of methods including deep learning);

- Logic- and knowledge-based approaches (including knowledge representation, inductive (logic) programming, knowledge bases, inference/deductive engines, (symbolic) reasoning, and expert systems);

- Statistical approaches, Bayesian estimation, search and optimization methods.

As we can see from the list above, the legislators are trying to avoid any possible loopholes and even classify 'statistical approaches' as Al, although few will attribute machine learning features to regression analysis, which provides the simplest data-based predictions for 'traditional statistics'. On the other hand, the concept fails to cover the technologies of quantum computing or 'edge' computing. ${ }^{3}$ Furthermore, the proposal includes a provision for the 'regulatory sandboxes' that supposedly would not hinder the development of innovations (art. 54), which albeit raises questions on possible data protection loopholes, as it is not clear if the sandbox eliminates the GDPR mandate over the experiment. It is also hard to disagree with the meticulous analysis performed by S. Ranchordas (2021) regarding the dependence of sandbox success on the quality of the experiment design and its compatibility with the rule of law principles - fair law ceases to exist once it becomes incomprehensible.

Potential caveats and threats of $\mathrm{Al}$ were made at the dawn of its development and inspired Isaac Asimov to formulate the Three Laws of Robotics. ${ }^{4}$ Although the spectrum of Al opportunities, risks, and dangers has been extensively analyzed in recent years (Dwivedi, 2019), ${ }^{5}$ we would like to highlight the specific factors that have been pushing forward the Al agenda at the EU level. Firstly, the EU finds itself in a race with the two other superpowers (the US and China) to dominate in attracting innovation while remaining a legal trendsetter. Secondly, the bloc is evidently eager to avoid a patchwork of national laws on Al that would undermine the global competitive ability of the Union. Minor discrepancies have already been showcased in the national Al Strategies of Member States, although most of them declared that they intended to follow a multi-lateral European approach in the future, ${ }^{6}$ if it is developed. Thirdly, as Al systems are often reliant on Big Data, they are already addressed to some extent by the GDPR (2018), but definitely require a more detailed regulation on such issues as those related to the deployment of the technology in law enforcement, healthcare, employment, education, public services, trade, and critical infrastructure to prevent potential harm. Lastly, the rapidly developing field needs a timely legislative approach, as research often progresses faster than the bureaucratic mechanisms of approving a multi-lateral agreement. These circumstances largely explain the urge of the European Commission (hereinafter - EC) to present a proposal as soon as April 2021, only three years after issuing the first communication on this topic (in comparison, the developing of GDPR started in 2011).

3. EUR-Lex-32006L0042. Directive 2006/42/EC of the European Parliament and the Council of 17 May 2006 on machinery and amending Directive 95/16/EC (recast), Official Journal L 157, 9 June 2006, pp. 24-86.

4. EUR-Lex-32014L0053. Directive 2014/53/EU of the European Parliament and of the Council of 16 April 2014 on the harmonization of the laws of the Member States relating to the making available on the market of radio equipment and repealing Directive 1999/5/EC Official Journal L 153, 22 May 2014, pp. 62-106.

5. EUR-Lex-52018DC0237. European Commission. 2018, April 25. Communication from the Commission to the European Parliament, the European Council, the Council, the European Economic and Social Committee and the Committee of the Regions Artificial Intelligence for Europe [online]. Available at: https://eur-lex.europa.eu/legal-content/EN/TXT/?uri=COM\%3A2018\%3A237\%3AFIN

6. European Commission (2020). "White Paper on Artificial Intelligence: a European approach to excellence and trust". In: European Commission [online]. Available at: https://ec.europa.eu/info/publications/white-paper-artificial-intelligence-european-approach-excellence-and-trust_en 


\section{The European policy response to Al challenges (2018-2021)}

As mentioned above, by early 2018 the EU found itself lagging behind its competitors in terms of unanimous policy response to the rapid growth of Al-based innovations. By then, the US government had already presented two policy documents-National Artificial Intelligence Research and Development Strategic Plan ${ }^{7}$ and 'Preparing for the Future of Artificial Intelligence' report, 8 with a wide array of planned research, especially in the area of military technologies (Evans, 2020). Being one of the leaders in Al research, with its prominent universities and start-ups, accounting for $32 \%$ of the global Al research market (Introna, 2016), the EU fell short of outperforming the US and China in private investment in the sector. ${ }^{9}$ Thus, the policy action at that point was caught between two opposing approaches offered by the 'ethicists', or stringent GDPR proponents on the one hand, and 'self-regulation' advocates on the other hand. ${ }^{10}$ As revealed later on, the latter has been represented in EU Commission expert circles to a greater extent (Johnson, 2019), although the chances of making a U-turn towards informal regulation have been largely decreased by the enacted GDPR and its core concept of the right to know why exactly a certain data-based decision has been made. Further steps taken by the European stakeholders can be organized into the following streams - communication of the strategic plans and debating of the proposals, research on risks and benefits, and legislating.

\subsection{Communication}

Debates on the need to regulate the field of Al at supranational level have officially kicked off with the arrival of European Parliament resolution with recommendations to the Commission on Civil Law Rules on Robotics (2017), that has set out the key principles concerning the development of robotics and Al for civil use, addressed main spheres of its application, liability issues and urged the EC to report to the European Parliament on the 'latest developments in robotics... on an annual basis'. Moreover, the document has stressed the utmost importance of safeguarding human control over $\mathrm{Al}$ and resolving possible ethical issues, e.g. an emotional connection between humans and robots.

This wake-up call has resulted in the EC issuing an 'Al for Europe' Communication, that has marked the launch of an ambitious European Al initiative, aimed at boosting innovation in public and private sectors, along with creating 'an appropriate ethical and legal framework' (Kelly, 2020). The text of the EC Communication (and the original Motion) offered to the reader a plethora of references to images of artificial intelligent creatures from mythology and classic literature, clearly a pedagogical maneuver that has however added confusion to the envisioned Al-driven future (Lee, 2018). The ambitious document paved the way towards creating an inclusive European Al Alliance discussion forum, as well as a joint Coordinated Plan on Al of the EC and Member States. Twenty-five Member States later signed a Declaration of Cooperation on Al. Shortly afterwards, the EC Joint Research Centre (JRC) together with the Directorate General for Communications Networks, Content and Technology launched Al Watch - the research monitor of policy initiatives and Al progress for implementing the European Strategy for Al.

In April 2021, the Coordination Plan has been updated with regards to the potential of Al ecosystems, at the service of the Green Deal and to address the aftermath of the COVID-19 pandemic, and the key priorities for the future are: creating favourable conditions for putting the locally developed Al products on the global market, securing fundamental rights protection and contributing joint efforts to six vital policy areas - environment, healthcare, robotics, law enforcement, infrastructure and agriculture (Maas, 2019). It is worth noting that policy-making in the EU has been recently subject to a paradigm shift towards

7. European Commission (2021). "Annexes to the Communication from the Commission to the European Parliament, the European Council, the Council, the European Economic and Social Committee and the Committee of the Regions; Fostering a European approach to Artificial Intelligence". In: European Commission DS [online]: Available at: https://digital-strategy.ec.europa.eu/en/library/coordinated-plan-artificial-intelligence-2021-review

8. European Union Agency for Cybersecurity (2020). "Artificial Intelligence Cybersecurity Challenges". In: ENISA [online]. Available at: https://www.enisa.europa.eu/publications/artificial-intelligence-cybersecurity-challenges

9. ISO/IEC JTC 1/SC 42 Artificial intelligence [online] [2021]. Available at: https://www.iso.org/committee/6794475.html

10. ISO/IEC JTC 1/SC 42 Artificial intelligence [online] [2021]. Available at: https://www.iso.org/committee/6794475.html 
professionalization (Maedche et al., 2019) and, e.g., the aforementioned policy areas selection was based on suggestions from the Member States and practical evidence.

In 2019, the EC issued another Communication, titled 'Building Trust in Human Centric Al', reassuring the Union to place its trust on developing further guidelines for trustworthy $\mathrm{Al}$ and encouraging stakeholders to give feedback on the respective guidelines (McCauley, 2007).

\section{Research}

As mandated by the Communication on Al for Europe, the EC has been annually reporting on the safety and liability legal frameworks for Al, Internet of Things (IOT) and other data-driven technical solutions, in order to identify the gaps that will be further bridged. In 2020, the research has drawn the attention of policymakers to the shortcomings in the General Product Safety Directive, Machinery Directive, the Radio-Equipment Directive and mentioned the forthcoming 'New Legislative Framework'. It has also been indicated that national laws can potentially cover the burden of proof issues in case of damage done by an automated vehicle (Meyer, 2018).

Anyhow, the core part of the research on formulating $\mathrm{Al}$ policy has been delegated by the EC to the newly established High-Level Expert Group on Artificial Intelligence (hereinafter - HLEG), tasked to compose AI Ethics Guidelines and Policy and Investment Recommendations, that will become a roadmap for further legislating process and policy-making. Following the records of the group meetings, although the group has been challenged because of the experts diverse backgrounds and short deadlines, they have managed to present an ambitious yet practical set of rules and safe-guards and given a call to elaborate a holistic European legal instrument (Nífhaoláin et al., 2020).

Another EU task force focused on the future of $\mathrm{Al}$ is the Ad-Hoc Working Group on Artificial Intelligence Cybersecurity at the EU Agency for Cybersecurity (ENISA), which recently issued its first report on Al Cybersecurity Challenges (Perrault et al., 2019). The document has developed a taxonomy of Al threats and allocated them into the following blocks: nefarious activity, eavesdropping, physical attacks, unintentional damage, failures, outages, disaster, and legal issues. The latter has particularly mentioned 'corruption of data indexes, profiling of end-users, vendor lock-in, weak requirements analysis, lack of data governance policies, lack of data protection compliance of third parties, SLA"1 breach' (Perrault et al., 2019).

Although the Council of Europe is a non-EU institution, the overview of Al-related research and reporting activities in Europe would not be complete without the recent Feasibility Study of its Ad Hoc Committee on Artificial Intelligence (CAHAI), issued in December 2020. The report has identified the challenges of Al systems for human rights, and identified several possible tracks to address them:

1) To amend the existing binding agreements;

2) To adopt a new binding legal instrument

3) To develop soft law at the level of CoE or Member States.

\section{Regulation}

Against the solid research background, in April 2021 the EC has presented the long-awaited pioneer proposal for a comprehensive EU Al regulation. As explained in the memorandum, the goal of the Union has remained the same - to build an innovator-friendly system of Al development guidelines and rule out the risks of privacy abuse and drooping into a dystopian techno-totalitarianism. The scope of the proposal is relatively wide - both private actors' and public authorities' activities, e.g., recidivism likelihood scoring and grading school entrance exams will be subject to thorough control. It is also remarkable that the Commission does not rely only on the legislative restrictions to be imposed, but also encourages service providers to introduce their soft-law tools - codes of conduct. These documents can be complemented by the internal self-reporting and raising awareness measures taken by the industry, which is also positive from the perspective of the funding required to implement the proposal.

Special focus has been made on the proposed taxonomy of Al systems - into those posing 'minimal risk', 'limited risk', 'high risk' and 'unacceptable risk'. The latter implies violating fundamental human rights, e.g., governmental scoring systems, live remote biometrical identification (unless required by urgent emergency measures). If an

11. Abbr. for service-level agreement 
algorithm is 'high-risk', i.e. its use impacts fundamental rights adversely, the authorizer is obliged to maintain:

- Adequate risk assessment and mitigation systems.

- High quality of the datasets feeding the system to minimise risks and discriminatory outcomes.

- Logging of activity to ensure traceability of results.

- Detailed documentation providing all information necessary on the system and its purpose for authorities to assess its compliance.

- Clear and adequate information to the user.

- Appropriate human oversight measures to minimise risk.

- High level of robustness, security, and accuracy. ${ }^{12}$

Limited risk is associated with cases in which Al can be confused with a live person (chat bot), thus automated tools must be revealed. Finally, the rest of Al systems can be deployed without any restrictions. Future standardization and implementation of the new guidance will be delegated to a new watchdog institute, European Al Board.

The chosen risk-based approach to the regulation is probably the most organic one, however, one must bear in mind that there is no silver bullet for regulating something as complex and multi-layered as the $\mathrm{Al}$, and problems may occur as well. Calibrating possible breaches of the standards and converting them into a simplified four-tier system can turn out to be over-simplistic and seize to exist after the first major scandal. This approach also raises ethical issues, as 'minimal' or 'acceptable' risk suggests a trade-off between the complicit needs.

The clarity of the regulation must appeal to the entrepreneurs, as opposed to the countries without sector-specific restriction. Although the draft $\mathrm{Al}$ regulation is already subject to public discussions until July 2021, the opposition among some businesses has already been fierce - developers and experts have repeatedly criticized the 'loose' definitions and huge costs that vendors would be required to invest in order to comply with the new framework (Ranchordas, 2021). Another controversy has been exposed by human rights defenders: on the one hand, the proposed framework intends to ban the 'remote biometric identification systems in publicly accessible spaces for the purpose of law enforcement'. On the other hand, contrary to the previously leaked document, the published version adds an exception that opens the door to Al-powered surveillance if allocating a suspect 'of any criminal act that carries a minimum three-year sentence'. Although such action would require prior approval from court, it is clear that this clause may provide a mass-scale violation of human rights. ${ }^{13}$

The experts are also concerned with the rather limited scope of the Al regulation - namely, leaving behind the lethal autonomous weapon systems (LAWS), civil liability, intellectual property and competition issues arising from the use of Al. Omitting the use of $\mathrm{Al}$ in military purposes could be explained by the popular opinion on the Al technologies as rather an improvement for other operations, than a way to develop completely new ones, which is sometimes criticized as being 'linear' (Russell \& Bohannon, 2015) if not misleading. Today the need for international control over military Al became evident - such framework must compliment ethics and legality with strategic goals and consider the arsenal of Al-powered arms being largely more extensive than the kinetic autonomous weapons systems (Schafer, 2016). The next point of critique, the lack of new elaborations on the civil liability, may be explained by the intention of the EU legislature to amend the Product Liability Directive with respective provisions, already reflected in the White Paper on Al (Schuett, 2019). However, one should bear in mind that this instrument has been developed in 1985 and does not fully match the technological challenges of the modern era (Smuha, 2019). Finally, the challenges of $\mathrm{Al}$ technologies to intellectual property rights system are two-fold: firstly, businesses seek to patent Al solutions, which is not possible yet under the European Patent Convention, unless it is as a 'subgroup of computer-implemented inventions' (Stahl, 2021). Secondly, Al has already been denied twice for registration as an inventor by the European Patent Office, based on the

12. EUR-Lex-52021PC0206. Proposal for a Regulation of the European Parliament and of the Council Laying Down Harmonised Rules on Artificial Intelligence (Artificial Intelligence Act) and Amending Certain Union Legislative Acts (2021), Brussels, 21 April.

13. EUR-Lex-32016R0679. Regulation (EU) 2016/679 of the European Parliament and of the Council of 27 April 2016 on the protection of natural persons with regard to the processing of personal data and on the free movement of such data, and repealing Directive 95/46/ EC (General Data Protection Regulation). Official Journal L119, 4 May 2016, pp. 1-88. 
lack of legal personality (Taube, 1961), which could also be reflected in the holistic proposal.

Anyhow, when contemplating the possible benefits and shortcomings of the proposed Al regulation, we should remember that delivering the proposal is only the first step on the long road of legislative procedures, that takes up to six years to make a comprehensive directive such as GDPR to become fully enforceable all over the Union. The European Parliament will hold several rounds of debate, most importantly - trilogues, defined as 'informal meetings attended by representatives of the Parliament (rapporteur and, where appropriate, shadow rapporteurs), the Council (chair of the working party and/or Committee of Permanent Representatives), and the Commission (department responsible for the dossier and the Commission's Secretariat-General)'. After the Parliament and the Council of the Union reach an agreement, the act is adopted by both and published in the OJEU. Member states are usually given another two years to adopt their legislation and adjust the institutional framework, with the total timeline of up to six years. This circumstance puts a burden on the regulation creators, to keep an eye on technological advances and constantly update the regulation until it's adopted in Brussels. Finally, Member states may also put significant barriers for the regulation to become a new reality. As proven by the GDPR case, ${ }_{1}^{14}$ despite the law already being directly enforceable across the EU, some member states may still be reluctant to comply with the new standards. It is also highly likely that the new policy will trigger entrepreneurs and activists to discuss its acceptability through the prism of local constitutional and competition law (Troitino, 2014).

If enacted, the $\mathrm{Al}$ regulation can also influence international technical standards on the use of Al. In general, the role of international standards in the EU can be described as a soft law. ${ }^{15}$ Although the standards remain voluntary by nature, they provide building confidence in the market and make the compliance with a particular directive auditable by an independent third party. As of today, ISO/IEC JTC 1SC 42, the joint subcommittee of the ISO (International Organisation for Standardization) and the IEC (International Electrotechnical Commission) has already published eight standards on Al ecosystems, and 22 more are currently under development. ${ }^{16}$ Hence, after adopting the regulation, the European Commission may either request one of the European Standards Organisation: CEN (European Committee for Standardization), CENELEC (European Committee for Electrotechnical Standardization), or ETSI (European Telecommunications Standards Institute) to develop a harmonised standard, that would provide the industry stakeholders with a clear compliance algorithm, or rely on the assumption that the forthcoming international Al standards will incorporate fundamental European values and a risk-based approach. However, according to the latest report published by the CEN-CENELEC Focus Group, the international standards do not address all the societal and sovereignty concerns that are relevant for the EU context, although further technical cooperation with the ISO and IEC continues. ${ }^{17}$

In addition to the presented regulation, the EU will take further steps to regulate Al. Reportedly, after the core Al regulation has gone through the debating phase, the European Commission is going to develop amendments to the Product Liability Directive and the General Product Safety Directive. Although it's impossible to make the Al-related legislation 'future-proof' given the nature of the technology, the Commission will still try to avoid loopholes for corporations, however these limitations should not scare the big data giants off to other jurisdictions. Overall, it is

14. European Commission (2019). "Communication from the Commission to the European Parliament, the Council, the European Economic and Social Committee and the Committee of the Regions-Building Trust in Human Centric Artificial Intelligence (COM-2019-168)". In: European Commission DS [online]. Available at: https://digital-strategy.ec.europa.eu/en/library/communication-building-trust-human-centric-artificial-intelligence

15. EUR-Lex-52020DC0064. Report From The Commission To The European Parliament. The Council And The European Economic And Social Committee Report on the safety and liability implications of Artificial Intelligence, the Internet of Things and robotics [online]. Available at: https://eur-lex.europa.eu/legal-content/en/TXT/?qid=1593079180383\&uri=CELEX\%3A52020DC0064

16. European Commission (2021). "Europe fit for the Digital Age: Commission proposes new rules and actions for excellence and trust in Artificial Intelligence". European Commission [online]. Available at: https://ec.europa.eu/commission/presscorner/detail/en/ip_21_1682

17. National Science and Technology Council (2016). "Preparing for the Future of Artificial Intelligence". In: Obama White House [online]. Available at: https://obamawhitehouse.archives.gov/sites/default/files/whitehouse_files/microsites/ostp/NSTC/preparing_for_the_future_of_ai.pdf 
easy to predict the potentially catalyst impact of the Al regulation on businesses, corporations erecting another level of the compliance system and the inevitable confusion among different stakeholders. While NGOs and unions will be dissatisfied with the act falling short of protecting workers from Al-performed quality control or profiling, entrepreneurs will blame it as a compliance nightmare.

\section{Conclusions}

The advent of the Al era has been envisioned since the 1950s, but only five years ago the technology became omnipresent in our lives. The marketing power of the 'Al' brand has maybe not yet reached its peak, though over $40 \%$ of European self-proclaimed 'Al start-ups' reportedly have nothing in common with the disruptive technology. Meanwhile, some corporations that already use it for recruiting or attracting new users often wish to avoid responsibility for possible racial discrimination or privacy abuse.
As noted above, the prospective EU regulation will take at least four years to be adopted, which will then show the efficacy of the chosen regulation model in real-life conditions and maybe even replicate the 'California effect'18 of the GDPR. In comparison to a more relaxed US legislation, the consolidated EU bill may face long odds in the race for fast economic revenue but protecting the Union against mass surveillance and discrimination is a sustainable way to stronger democracy and a higher level of public trust in Al solutions, that could not be achieved by Member States individually. It is also worth mentioning that the EU has set an ambitious goal to build robust datasets and computation infrastructure that would secure a unique competitive advantage in capacity for research excellence. As recently assessed by the European Parliament, by 2030 , a common Al regulatory effort can bring the EU $€ 294.9$ billion in additional GDP and 4.6 million additional jobs by $2030 . .^{19}$ If adopted, the risk-based human-centric framework will effectively influence EU allies and boost sustainable economic growth across the globe.

18. The phenomenon takes place when a jursidiction 'exports' own strict standards to other countries due to a greater level of globalization, as opposed to the 'race to the bottom' trend (EUR-Lex-12007L/TXT).

19. National Science and Technology Council (2016). "The National Artificial Intelligence Research And Development Strategic Plan". In: Networking and Information Technology Research and Development Program [online]. Available at: https://www.nitrd.gov/pubs/national_ai_rd_strategic_plan.pdf 


\section{References}

AGAR, J. (2020). "What is science for? The Lighthill report on artificial intelligence reinterpreted". In: British Journal for the History of Science, pp. 289-310 [online]. DOI: https://doi.org/10.1017/ S0007087420000230

ARRIETA, A. B.; DIAZ RODRIGUEZ, N.; DEL SER, J.; BENNETOT, A.; TABIK, S.; BARBADO, A.; HERRERA, F. (2020). "Explainable Artificial Intelligence (XAI): Concepts, taxonomies, opportunities and challenges toward responsible Al". In: Information Fusion, pp. 82-115 [online]. DOI: https://doi. org/10.1016/j.inffus.2019.12.012

BBC (2021). “EU artificial intelligence rules will ban 'unacceptable' use". In: BBC [online]. Available at: https://www.bbc.com/news/technology-56830779

BLACK, J.; MURRAY, A. (2019). "Regulating Al and Machine Learning: Setting theRegulatory Agenda". In: European Journal of Law and Technology.

BÜTTNER, S. M.; LEOPOLD, L.; MAU, S.; POSVIC, M. (2015). “Professionalization in EU Policy-Making? The topology of the transnational field of EU affairs". In: European Societies, pp. 569-592 [online]. DOI: https://doi.org/10.1080/14616696.2015.1072229

CABRAL, T. S. (2020). "Liability and artificial intelligence in the EU: Assessing the adequacy of the current Product Liability Directive". In: Maastricht Journal of European and Comparative Law, pp. 615-635 [online]. DOI: https://doi.org/10.1177/1023263X20948689

CEN-CENELEC (2020). "Road Map on Artificial Intelligence (AI)". In: CEN-CENELEC. Available at: https://ftp.cencenelec.eu/EN/EuropeanStandardization/Sectors/AI/CEN-CLC_FGR_RoadMapAI.pdf

DE HERT, P.; PAPAKONSTANINOU, V.; KAMARA, I. (2016). "The cloud computing standard ISO/IEC 27018 through the lens of the EU legislation on data protection". In: Computer Law and Security Review, pp. 16-30 [online]. DOI: https://doi.org/10.1016/j.clsr.2015.12.005

DELPONTE, L. (2018). "European Artificial Intelligence (AI) leadership, the path for an integrated vision". In: Eurocities [online]. Available at: https://nws.eurocities.eu/MediaShell/media/European_Al_study.pdf

DWIVEDI, Y. K. (2019). "Artificial Intelligence (AI): Multidisciplinary perspectives on emerging challenges, opportunities, and agenda for research, practice and policy". In: International Journal of Information Management.

EUR-Lex-12007L/TXT. Treaty of Lisbon amending the Treaty on European Union and the Treaty establishing the European Community, signed at Lisbon (2007), Official Journal C306, 17 December, pp. $1-271$

EUR-Lex-12012P/TXT. Charter of Fundamental Rights of the European Union. Official Journal C326, 26 October, pp. 391-407.

EUR-Lex-32001L0095. Directive 2001/95/EC of the European Parliament and of the Council of 3 December 2001 on General Product Safety, Official Journal L 11, 15 January 2002, pp. 4-17.EUR-Lex32006 L0042. Directive 2006/42/EC of the European Parliament and of the Council of 17 May 2006 on machinery and amending Directive 95/16/EC (recast), Official Journal L 157, 9 June 2006, pp. 24-86.

EUR-Lex-32014L0053. Directive 2014/53/EU of the European Parliament and of the Council of 16 April 2014 on the harmonisation of the laws of the Member States relating to the making available on the market of radio equipment and repealing Directive 1999/5/EC Official Journal L 153, 22 May 2014, pp. 62-106. 
EUR-Lex-32016R0679. Regulation (EU) 2016/679 of the European Parliament and of the Council of 27 April 2016 on the protection of natural persons with regard to the processing of personal data and on the free movement of such data, and repealing Directive 95/46/EC (General Data Protection Regulation). Official Journal L119, 4 May 2016, pp. 1-88.

EUR-Lex-52018DC0237. European Commission. 2018, April 25. Communication from the Commission to the European Parliament, the European Council, the Council, the European Economic and Social Committee and the Committee of the Regions Artificial Intelligence for Europe [online]. Available at: https://eur-lex.europa.eu/legal-content/EN/TXT/?uri=COM\%3A2018\%3A237\%3AFIN

EUR-Lex-52020DC0064. Report From The Commission To The European Parliament. The Council And The European Economic And Social Committee Report on the safety and liability implications of Artificial Intelligence, the Internet of Things and robotics [online]. Available at: https://eur-lex.europa. eu/legal-content/en/TXT/?qid=1593079180383\&uri=CELEX\%3A52020DC0064

EUR-Lex-52021PC0206. Proposal for a Regulation of the European Parliament and of the Council Laying Down Harmonised Rules on Artificial Intelligence (Artificial Intelligence Act) and Amending Certain Union Legislative Acts (2021), Brussels, 21 April.

European Commission (2019). "Communication from the Commission to the European Parliament, the Council, the European Economic and Social Committee and the Committee of the Regions-Building Trust in Human Centric Artificial Intelligence (COM-2019-168)". In: European Commission DS [online]. Available at: https://digital-strategy.ec.europa.eu/en/library/communication-building-trust-human-centric-artificial-intelligence

European Commission (2020). "White Paper on Artificial Intelligence: a European approach to excellence and trust". In: European Commission [online]. Available at: https://ec.europa.eu/info/publications/white-paper-artificial-intelligence-european-approach-excellence-and-trust_en

European Commission (2021). "Annexes to the Communication from the Commission to the European Parliament, the European Council, the Council, the European Economic and Social Committee and the Committee of the Regions; Fostering a European approach to Artificial Intelligence". In: European Commission DS [online]: Available at: https://digital-strategy.ec.europa.eu/en/library/ coordinated-plan-artificial-intelligence-2021-review

European Commission (2021). "Europe fit for the Digital Age: Commission proposes new rules and actions for excellence and trust in Artificial Intelligence". In: European Commission [online]. Available at: https://ec.europa.eu/commission/presscorner/detail/en/ip_21_1682

European Union Agency for Cybersecurity (2020). "Artificial Intelligence Cybersecurity Challenges". In: ENISA [online]. Available at: https://www.enisa.europa.eu/publications/artificial-intelligence-cybersecurity-challenges

EVAS, T. (2020). "European framework on ethical aspects of artificial intelligence, robotics and related technologies". In: European Parliament [online]. Available at: https://www.europarl.europa.eu/ RegData/etudes/STUD/2020/654179/EPRS_STU(2020)654179_EN.pdf

INTRONA, L. D. (2016). "Algorithms, governance and governmentality: On governing academic writing". In: Science, Technology \& Human Values, pp. 17-49 [online]. DOI: https://doi. org/10.1177/0162243915587360

ISO/IEC JTC 1/SC 42 Artificial intelligence [online] [2021]. Available at: https://www.iso.org/committee/6794475.html

JOHNSON, J. (2019). "The end of military-techno Pax Americana? Washington's strategic responses to Chinese Al-enabled military technology". In: The Pacific Review, pp. 351-378 [online]. DOI: https:// doi.org/10.1080/09512748.2019.1676299 
KELLY, É. (2020). "EU struggles to go from talk to action on artificial intelligence". In: The Science Business Network [online]. Available at: https://sciencebusiness.net/news/eu-struggles-go-talk-action-artificial-intelligence

LEE, N. (2018). "Detecting racial bias in algorithms and machine learning". In: Journal of Information, Communication and Ethics in Society, pp. 252-260 [online]. DOI: https://doi.org/10.1108/ JICES-06-2018-0056

MAAS, M. (2019). "How viable is international arms control for military artificial intelligence? Three lessons from nuclear weapons". In: Contemporary Security Policy, pp. 285-311 [online]. DOI: https:// doi.org/10.1080/13523260.2019.1576464

MAEDCHE, A.; LEGNER, C.; BENLIAN, A.; BERGER, B.; GIMPEL, H.; HESS, T.; SÖLLNER, M. (2019). "Albased digital assistants". In: Business \& Information Systems Engineering, pp. 535-544 [online]. DOI: https://doi.org/10.1007/s12599-019-00600-8

MCCAULEY, L. (2007). "Al armageddon and the three laws of robotics". In: Ethics and Information Technology, pp. 153-164 [online]. DOI: https://doi.org/10.1007/s10676-007-9138-2

MEYER, D. (2018). "Most member states won't be ready for GDPR". In: IAPP [online]. Available at: https://iapp.org/news/a/most-member-states-wont-be-ready-for-gdpr/

NATIONAL SCIENCE AND TECHNOLOGY COUNCIL (2016). "Preparing for the Future of Artificial Intelligence". In: Obama White House [online]. Available at: https://obamawhitehouse.archives. gov/sites/default/files/whitehouse_files/microsites/ostp/NSTC/preparing_for_the_future_of_ ai.pdf

NATIONAL SCIENCE AND TECHNOLOGY COUNCIL (2016). "The National Artificial Intelligence Research And Development Strategic Plan". In: Networking and Information Technology Research and Development Program [online]. Available at: https://www.nitrd.gov/pubs/national_ai_rd_strategic_plan.pdf

NÍFHAOLÁIN, L.; HINES, A.; NALLUR, V. (2020). "Assessing the Appetite for Trustworthiness and the Regulation of Artificial Intelligence in Europe". 28th Irish Conference on Artificial Intelligence and Cognitive Science-AICS. In: Research Repository UCD [online]. Dublin: UCD. Available at: https:// researchrepository.ucd.ie/handle/10197/12396

PERRAULT, R.; SHOHAM, Y.; BRYNJOLFSSON, E.; CLARK, J.; ETCHEMENDY, J.; GROSZ, B.; NIEBLES, J. C. (2019). "The Al Index 2019 Annual Report". In: Human-Centered Al Institute [online]. Stanford: Stanford University. Available at: https://hai.stanford.edu/sites/default/files/ai_index_2019_report.pdf

RANCHORDAS, S. (2021). "Experimental Regulations for Al: Sandboxes for Morals and Mores". In: SSRN, no. 7 [online]. Groningen: University of Groningen, Faculty of Law Research Paper. Available at: SSRN: https://ssrn.com/abstract=3839744. DOI: https://doi.org/10.5771/2747-5182-2021-1-86

RUSSELL, S.; BOHANNON, J. (2015). "Artificial intelligence. Fears of an Al pioneer". In: Science, vol. 349, no. 6245 [online]. DOI: https://doi.org/10.1126/science.349.6245.252

SCHAFER, B. (2016). "Closing Pandora's box? The EU proposal on the regulation of robots". In: The journal of the Justice and the Law Society, pp. 55-68. Brisbane: University of Queensland.

SCHUETT, J. (2019). "A Legal Definition of Al". In: SSRN [online]. DOI: https://doi.org/10.2139/ ssrn.3453632

SMUHA, N. A. (2019). "The EU Approach to Ethics Guidelines for Trustworthy Artificial Intelligence". In: Computer Law Review International, pp. 97-106 [online]. DOI: https://doi.org/10.9785/cri-2019200402 
STAHL, B. C. (2021). "EU is cracking down on Al, but leaves a loophole for mass surveillance". In: The Conversation [online]. Available at: https://theconversation.com/eu-is-cracking-down-on-ai-butleaves-a-loophole-for-mass-surveillance-159421

TAUBE, M. (1961). Computers and Common Sense. The Myth of Thinking Machines. New York: Columbia University Press [online]. DOI: https://doi.org/10.7312/taub90714

THORNTON, R.; MIRON, M. (2020). "Towards the 'Third Revolution in Military Affairs' The Russian Military's Use of Al-Enabled Cyber Warfare". In: RUSI Journal [online], pp. 12-21. DOI: https://doi.org/1 0.1080/03071847.2020.1765514

TOTSCHNIG, W. (2020). "Fully autonomous AI". In: Science and Engineering Ethics, no. 26, pp. 24732485 [online]. DOI: https://doi.org/10.1007/s11948-020-00243-z

TROITINO, D. (2014). "The Single European Act-the Creation of the Interior Market in Europe". In: Journal on Legal and Economic Issues of Central Europe, pp. 8-14.

VINCENT, J. (2021). "EU outlines wide-ranging Al regulation, but leaves the door open for police surveillance" [online]. In: The Verge. Available at: https://www.theverge.com/2021/4/21/22393785/ eu-ai-regulation-proposal-social-credit-ban-biometric-surveillance-exceptions

VOGEL, D. (1995). Trading Up: Consumer and Environmental Regulation in a Global Economy. Cambridge: Harvard University Press.

WACHTER, S.; MITTELSTADT, B.; RUSSELL, C. (2020). "Why Fairness Cannot Be Automated: Bridging the Gap Between EU Non-Discrimination Law and AI". In: SSRN Electronic Journal [online]. DOI: https://doi.org/10.2139/ssrn.3547922

WANG, P. (2008). "What Do You Mean by "Al"?". In: Frontiers in Artificial Intelligence and Applications, pp. $362-373$.

WEARN, O. R.; FREEMAN, R.; JACOBY, D. M. (2019). "Responsible Al for conservation". In: Nature Machine Intelligence, no. 1, pp. 72-73 [online]. DOI: https://doi.org/10.1038/s42256-019-0022-7

YU, R.; ALI, G. S. (2019). "What's inside the Black Box? Al Challenges for Lawyers and Researchers". In: Legal Information Management, vol. 19, no.1, pp. 2-13 [online]. DOI: https://doi.org/10.1017/ S1472669619000021

ZAICHUK, M. (2018). "Patenting Artificial Intelligence and Machine Learning Innovations in Europe". In: Jones Day [online]. Available at: https://www.jonesday.com/en/insights/2018/10/patenting-artificial-intelligence-and-machine-lear

ZAICHUK, M. (2020). "IP Protection of Artificial Intelligence in Europe: Tailor-Made Solutions Required". In: Jones Day [online]. Available at: https://www.jonesday.com/en/insights/2020/04/ ip-protection-of-artificial-intelligence-in-europe

\section{Recommended citation}

SHUMILO, Olga; KERIKMÄE, Tanel (2021). "The European approach to building Al policy and governance: a haven for bureaucrats". IDP. Internet, Law and Politics E-Journal. No. 34. UOC [Accessed: dd/ mm/aa] http://dx.doi.org/10.7238/idp.v0i34.387744 
The texts published in this journal, unless otherwise indicated, are subject to a Creative Commons Attribution No Derivative Works 3.0 Spain licence. They may be copied, distributed and broadcast provided the the author, the journal and the institution that publishes them (IDP. Revista de Internet, Derecho y Política; UOC) are cited. Derivative works are not permitted. The full licence can be consulted on http://creativecommons.org/licenses/bynd/3.0/es/deed.es.

\author{
About the authors \\ Olga Shumilo \\ Tallinn University of Technology (TalTech) \\ olshum@taltech.ee
}

PhD student, writing her thesis on issues of legal framework. Doctoral student at Tallinn University of Technology, researching the drivers and barriers behind the adoption of artificial intelligence in judiciary. She is also currently teaching Criminal and Constitutional Law, and has contributed to several publications in the scope of EU Law and E-Governance. Olga has obtained her master's degree in law at the Yaroslav Mudryi National Law University (Kharkiv, Ukraine). In Ukraine, Olga has specialized in Criminology, particularly animal welfare.

\title{
ORCID: https://orcid.org/0000-0001-7251-7947
}

\section{Tanel Kerikmäe}

Tallinn University of Technology (TalTech)

tanel.kerikmae@taltech.ee

Professor of European Law and director of Tallinn Law School at Tallinn University of Technology; a board member of several high-ranked law journals and an author of more than 150 articles and publications, Tanel is active as an expert for public and private institutions, international organizations and has been the key expert of EU in Central Asia. He has been contributing to the research of European law and policies and created a research group of law \& tech that received significant funding from EU Commission (H2020, Jean Monnet Centre of Excellence), NATO, Folke Bernadotte Academy, USAID, Estonian Research Council etc. He serves as a President of the Estonian branch of European Community Studies Association and has been teaching and supervising at several universities in and outside Europe, including the Baltic States. Currently, prof. Kerikmäe is responsible for several international projects and related to international research cooperation networks. Moreover, his expertise also includes the topics on EU legal policies, digital single market, automatisation, legal impediments to new technologies, and augmented and artificial intelligence in legal practice.

ORCID: https://orcid.org/0000-0002-5972-827X

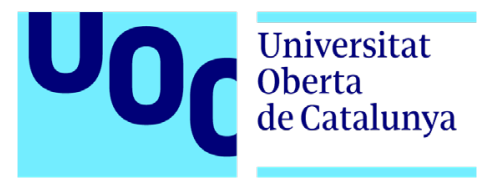

